\title{
Exploration on Practical Course Teaching Reform of Architectural Engineering Technology Major
}

\author{
Junwei Hou \\ Chongqing Vocational Institute of Engineering, Chongqing, 400055, China
}

Keywords: Architectural engineering technology major, Practical course, Teaching reform

\begin{abstract}
The course of architectural engineering technology is a strongly practical specialized course. Therefore, teachers can not impart theoretical knowledge simply in teaching and should meanwhile strengthen practical teaching. Practical course is set for academic practice of students. Factors such as incomplete course system and facility layout cause the failure of practical course of architectural engineering technology major to reach the standard and influence practical learning of students. This paper conducts brief analysis on existing problems of practical course of architectural engineering technology major, makes reasonable suggestions on course teaching reform and expects to provide effective basis for practical course teaching reform of architectural engineering technology major.
\end{abstract}

\section{Introduction}

Architectural engineering technology major mainly cultivates technical talents in architecture for the society. This requires students to have both adequate basic theoretical knowledge and strong practical ability. Therefore, practical course cannot be neglected in the teaching process. Higher vocational colleges have paid attention to this issue. In recent years, practical course has been widely applied to the teaching of architectural engineering technology major. However, factors such as course system, teaching resources and teacher quality cause inconspicuous effect of practical course. To improve the teaching effect of practical course and cultivate all-round talents with both theory and practice, it is inevitable to reform practical course.

\section{Premise of practical teaching reform}

Large quantity demanded of architectural engineering technical talents. With the development of social economy and urban-rural integrated planning, construction industry has developed rapidly and the quantity demanded of architectural talents has been constantly increasing. According to investigation, construction industry has a large quantity demanded of senior management talents; meanwhile, technical talents have a great market. However, college enrollment expansion in recent years causes the increase of college graduates in successive years and the increase of employment competitiveness of architectural technical talents. Talents with construction experience and good professional quality have great advantages in the recruitment process of construction industry. Currently, Chinese construction industry still has a good development prospect and cities, villages and towns are still in the peak time of construction. However, Chinese architectural enterprises have big problems in human resource management. Professionals and technical talents are lacking in architectural enterprises. In spite of this, graduates of architectural engineering technology major in China have a low employment rate. Reasons are that graduates have insufficient practical experience and weak business ability and theoretical knowledge in the school is obsolete and separated from the development and practice of actual construction industry. Therefore, architectural enterprises recruiting graduates have to spend a long time providing them with practical training and their manpower and material resources are wasted ${ }^{[1]}$.

Large space for improvement in practical teaching of architectural engineering technology. As practical teaching of architectural engineering technology in China has been implemented only for a short time, teaching concept and experience are lacking and there is a great gap from western developed countries. This shows that practical teaching of architectural engineering technology in 
China has a large space for improvement and also reminds China of rational reform and exploration in college practical teaching. German FH practical teaching mainly cultivates students' abilities of solving actual problems, including abilities of thinking, action, adaptation and learning, and allows students to treat problems scientifically in these four aspects, solve problems with effective methods, gain abilities of adaptation to the surrounding environment and response to emergency situations and accept new knowledge scientifically ${ }^{[2]}$.According to practical teaching in other countries, China should make corresponding adjustments in teaching system and concept, use overseas successful experiences for reference, reform practical teaching rationally based on the development of Chinese construction industry and the actual situation of talent demand and improve the efficiency of practical teaching of architectural engineering technology.

Status of Chinese practical teaching to be improved urgently. Currently, there are still many problems in the teaching process of colleges and universities in China, such as obsolete teaching mode, cliché course system, lack of talent training standard, immature teaching theory and system of practical course especially in strongly practical professional teaching, and incomplete teaching method and relevant supporting facilities. Such problems cause the separation of students' theoretical knowledge and practice and deficiencies in professional skills. Therefore, graduates are faced with great pressure in the employment process. The lack of theory and practice makes graduates require a long-time period for adaptation and training in work. Employers are unwilling to spend a lot of manpower and material resources training newcomers. Therefore, graduates have a small employment space and weak employment competitiveness. Specific reasons include the following: incomplete curriculum system, slow updating of theoretical knowledge and lack of practical course, which cause the failure of students to get effective practical exercise; unreasonable practical course setting, weak connection with practical work or loose course linking, causing the lack of students' practical ability; lack of practical teaching materials, causing the lack of necessary basis of practical teaching; deficient abilities of teachers in practical teaching - as teachers are always engaged in teaching work and have few practical experience, they are inclined to theoretical teaching in practical teaching, causing the failure to achieve the expected effect of practical teaching.

\section{Have in-depth knowledge of industry needs and establish practical teaching system}

Demands for engineering technical talents in construction industry. Architectural engineering technology major mainly cultivates technical talents in architectural engineering construction and management. Therefore, students majoring in architectural engineering technology should have not only basic knowledge and professional moral cultivation, good health and psychological quality, but also work abilities matching with practical needs, which are mainly manifested in basic professional knowledge, mastery of corresponding practical operation techniques in architectural engineering work and strong comprehensive abilities such as abilities of learning, thinking, innovation and interpersonal communication. They should also have professional basic skills in actual work such as computer operation, instrumentation and drawing and analysis of engineering drawings.

Establishment of practical teaching system. Curriculum setting of architectural engineering technology major is strongly pertinent. This major mainly cultivates technical applied vocational talents with high quality and strong skills. Practical teaching mainly cultivates professional skilled talents pertinently according to actual demands for talents in construction industry so as to meet demands of posts. Practical teaching system setting should center on the cultivation of practical talents with occupational abilities, be guided by actual work process and methods in construction industry, use theoretical teaching and practical teaching assessment as standard and use the method of university-enterprise cooperation. Practical teaching contents should reflect intensive training of basic operating skills and include practical teaching module for training students' creative ability, strengthen the improvement of students' basic professional skills and pay attention to the training of students' basic quality such as professional ethics and dedication spirit. The whole teaching system setting should accord with actual work contents, process and scene of construction. Meanwhile, the training of professional skills should be conducted by different levels in practical teaching. It is 
required to first train students' basic operating skills, then train their professional techniques on this basis and finally combine theory and practice and provide students with comprehensive skill training items. The principle of going from the easier to the more advanced, the part to the whole and the basis to the professional should be followed in the whole practical teaching process so that students can gradually master practical operating skills in architectural engineering technology. It is required to pay attention to the hierarchy and stage of teaching and establish a complete system with wide contents and certain depth in knowledge structure and technology. Meanwhile, the scientificalness, rationality and operability of teaching system should be guaranteed.

Refining of practical teaching system. Practical teaching system should be refined after establishment so as to guarantee the systematicness and operability of teaching. First, practical teaching can be divided into three major modules, i.e. basic skill training, professional skill training and comprehensive skill training ${ }^{[4]}$. Basic skill training mainly refers to training of basic operational abilities in construction industry, e.g. understandings of architectural engineering construction and use of tools. The training of basic skills can strengthen students' theoretical knowledge and meanwhile lay a foundation for the training of professional skills. Professional skill training can improve students' professional technical abilities on the basis of basic skills, such as foundation work, earthwork and construction site management. It is more systematic and can improve students' professional abilities. Comprehensive skill training involves common skills in comprehensive architectural engineering. Students are trained in practical teaching, e.g. students' graduation project and graduation practice. Comprehensive skill training can improve students' comprehensive practical abilities effectively and lay a solid foundation for their future work.

\section{Attach importance to training of practical skills and enrich teaching contents}

Teaching contents are the key of practical teaching. Practical teaching contents should be combined with the application of professional skills in contemporary construction industry. It is required to pay attention to the training of students' comprehensive skills, highlight professional core abilities and strengthen the training of students' professional ethics accomplishment

Pay attention to the improvement of basic skills. The training of basic skills is the foundation of practical teaching. Basic skill training is completed mainly through textbook experiments, including theoretical verification experiment and visit to engineering project construction, so that students can master basic architectural practice contents, have understandings of relevant instrument operation and lay a foundation for future professional skill operation and work practice.

Improvement of professional skills. Professional skills have a wide range, including technical abilities in engineering construction and other abilities related to engineering such as computer operation skills, information processing skills and teamwork skills. The improvement of professional skills is vital in practical teaching. It concerns students' professional level and ability after work and is the guarantee of competitiveness improvement in employment. Therefore, professional skill training should be implemented in practical teaching according to architectural engineering needs and relevant skill operation standards.

Improvement of comprehensive skills. Comprehensive skills are students' necessary abilities in construction work as well as core abilities in architectural engineering construction technologies. In comprehensive skill training, teaching contents should go from the easier to the more advanced so that students can expand basic skills horizontally and longitudinally and finally achieve the improvement of comprehensive technical abilities. Comprehensive skill training is completed mainly through students' graduate practice, graduation project and construction site simulation established in the school.

Combine work contents and practical teaching. Practical teaching mainly aims at allowing students to master practical technical operation abilities rapidly after graduation and increase architectural engineering experience and students' employment opportunities. Therefore, the basic principle of practical teaching is to combine it with work contents in architectural engineering industry and make practical teaching more pertinent. Work contents can be divided into different modules for situational teaching according to features of professional posts so that students can 
complete practical teaching in some field in the simulated situation and complete whole teaching contents through the simulation of each module.

Integrate vocational qualification certificate training into teaching. Talents cultivated by architectural engineering technology major are strongly professional. Therefore, students should reflect their professional level with relevant vocational qualification certificates. The integration of vocational qualification test training into practical teaching can strengthen the training of students' theoretical knowledge and practical skills, make teaching objectives more specific, shorten pre-job training time of students effectively and improve students' employment competitiveness due to relevant vocational qualification certificates.

\section{Strengthen training base construction and provide more practicing opportunities}

Strengthen on-campus training base construction. The construction of training base is the foundation of practical teaching. Therefore, the establishment of training base according with actual architectural engineering construction is the guarantee of practical teaching. The following basic principles should be followed in the construction of training base: 1. Advancement. Base construction must be advanced and adapted to modern architectural development so as to train talents adapted to contemporary development.2. Practicability. Base construction should be based on practicability. Each link of the base should have practical significance and maximize utilization.3. Comprehensiveness. Base construction aims at improving students' comprehensive technologies. Therefore, comprehensiveness is one of the necessary conditions of base construction.

Implement university-enterprise cooperative teaching and establish off-campus training base. On-campus training base has many deficiencies for students' practical teaching due to limitations of fund, place and technology. The establishment for off-campus training base through university-enterprise cooperation can provide students with more real training scenes and improve students' practical professional skills. Meanwhile, off-campus training base has more advantages in teaching. Technical backbone of enterprises and teachers jointly guide students in skill learning and provide more professional guidance for students' practice so as to improve the speciality of their practice. University-enterprise cooperation can provide effective approaches for students' employment. Students have more advantages in the competition at the same level through internship in enterprises.

\section{Conclusion}

The application of practical teaching in architectural engineering technology major can provide students with more practicing opportunities, improve their professional skills and increase competition capital of students in employment. However, there are many deficiencies in actual teaching. Schools and teachers are required to reform pertinently to improve the operability of practical teaching, strengthen the improvement of students' comprehensive technical abilities and cultivate comprehensive skilled talents.

\section{References}

[1] Wang Meifen. Establishment of Practical Teaching Quality Guarantee System of Higher Vocational Architectural Engineering Technology Major and Empirical Study. Education and Vocation, 2015(10):103-104.

[2] Hu Xingfu. Analysis on Guidelines on Construction of On-campus and Off-campus Training Base of Architectural Engineering Technology Major. Vocational Education Forum, 2012(3):76-78.

[3] Wang Junqiang. Discussions on Practical Training of Process in Higher Vocational Architectural Engineering Technology Major. Journal of Xuzhou Institute of Architectural Technology, 20066(1):73-75. 
[4] Liu Yongbing. Exploration on Reform of Practical Training of Graduates Majoring in Architectural Engineering Technology. New West (Second Half of the Month), 2007(1):161,192.

[5] Xu Yanhua, Zhao Yanmin. Reform and Exploration of Practical Training of Graduates Majoring in Architectural Engineering Technology. Shanxi Architecture, 2010,36(26):190-191. 